\title{
Analysis of the Determinants for Online Business Interest Among University Students
}

\author{
Dedy Husrizal Syah ${ }^{1 *}$, Haikal Rahman ${ }^{1}$, Azizul Kholis ${ }^{1}$, Faisal R Dongoran ${ }^{2}$ \\ ${ }^{1}$ State University of Medan, Medan, Indonesia \\ ${ }^{2}$ Muhammadiyah University of North Sumatera, Medan, Indonesia \\ *Corresponding author. Email: dedy@unimed.in
}

\begin{abstract}
This study aims to partially or simultaneously observe the influence of educational factors, environmental factors, and internet service availability factors on student interest in practicing online business. This study employed a survey method. The obtained sample of this study included 94 respondents, selected by purposive sampling method from the population of all study programs. Research information data was collected through a questionnaire instrument. Data analysis was performed through multiple regression technique. The results of this study indicate that partially variable education and availability of internet services had a significant effect on online business. However, environmental variables had no significant effect on online business. Simultaneously, the variables of education, environment, and availability of internet services had a significant effect on online business interests.
\end{abstract}

Keywords: Interests, Online Business, Education, Environment, Internet.

\section{INTRODUCTION}

The Covid-19 pandemic was initially declared endemic in Indonesia in March 2020, inevitably changing the lives of many people leading to the implementation of new habits. One of the most significant impacts has been economic changes in various sectors, such as termination of employment (PHK), affecting the income. However, this pandemic offers a bright spot behind the slumping economic situation. Technological developments give birth to new opportunities in particular, such as e-commerce. According to the Head of the Payment System Policy Department of Bank Indonesia (BI), Filianingsih Hendarta, e-commerce transactions rise by $26 \%$ during the pandemic [1]. Meanwhile, daily transactions also increased to IDR 4.8 million, and the percentage of new consumers rises to $51 \%$ during the pandemic.

The increase in the number of e-commerce customers was also reported by hosting service provider company such as Exabytes Indonesia. In the first seven months of 2020, numerous business people have been starting to move into "go-digital" by building an online platform for most business activities [2]. The increase in the number of customers in the form of PT or CV indicates an average of 38.3\% compared to last year performance. Even in February, the trend rose to $120 \%$ compared to that in last February of 2019. According to IdEA, e-commerce sales increased 25\% during the pandemic [3].

In addition, transaction volume increased by $78 \%$ compared to 2019. The growth of e-commerce significantly increased several times compared to the prediction. Hence, this phenomenon offers an opportunity, which opens the business exploitation particularly the online businesses, thereby generating the anticipated challenges. Business practitioners are demanded to profoundly capture the opportunities from this growing phenomenon, to innovate, to adapt and to develop their business [4].

According to the IBM web page, e-business is defined as a concept to convert the essence of business activities through the use of internet technology [5]. Ebusiness includes all activities related to the company's internal and coordination with suppliers and other external parties. Applying internet technology in conducting business also engages the sales and 
purchase transactions of goods, acknowledged as electronic commerce or e-commerce.

Thus, e-commerce plays a pivotal part of ebusiness related to both purchasing and selling goods and services via the internet. Such method additionally includes other supporting activities, which convey: advertising, marketing, customer service, security, delivery, and payment [6].

Instance includes the practice in some companies, such as Cisco Systems, 3M, and IBM, which are digital companies, by employing the internet to power their entire network aspects of their business. However, some other companies have not fully implemented digital yet; thereby attempting to transform into the digital integration with providers, customers, and employees [7].

Nonetheless, conducting the business or entrepreneurship under the platform of e-business as above, presents the challenge. Based on the results of a survey conducted by APJII, that only $14 \%$ of Indonesian internet users have ever practiced the online sales, further perceived that the reason of other internet users $(86 \%)$ ) are reluctant to practice online sales, due to reasons such as: fear of fraud $(41.3 \%)$, not understand how to practice $(27 \%)$, not practical $(22.4 \%)$ and other reasons [8].

In general, becoming a reliable online businessman requires creativity, innovation, including a strong interest. Interest refers to a mental set consisting of a mixture of feelings, hopes, convictions and tendencies that lead individuals to a certain choice. Interest affects a person's learning process and outcomes, because if someone learns something with great interest, it might lead to better results. In addition, a person's interest could be expressed through statements that depict a person's interest towards another object [9],[10].

Therefore, interest becomes the main rule in responding to something, including the interest in entrepreneurship among students, influenced by various factors, such as: (1) Education, if education is adequate then a person is assumed to be ready in becoming an entrepreneur and leading his subordinates; (2) Family and community environment, it is assumed that the more conducive the family, environment and surrounding community, the more it will encourage someone to become an entrepreneur; and (3) Availability of internet services, it is assumed that someone will be interested in becoming an entrepreneur because of the availability of reliable and affordable internet infrastructure [11],[12],[13].

Particularly, education serves as one of the important aspects to assist someone in running the business. Likewise, inadequate knowledge about a technology leads to a person's reluctance to do things using the technology [14]. Especially among young people, the results of the study indicate that Internet entrepreneurship training courses, seminars, and information dissemination become the main techniques that encourage young people to create internet businesses [15],[16].

Several previous studies provide evidence that environmental insight generates a relationship with entrepreneurship [17]. Other research also demonstrates that environmental factors affect start-up businesses [18]. There are however few studies focusing on the relationship between the availability of internet services and the interest in doing business, with several studies examine the relationship of information technology, including the internet application for work and business performance. Additionally, several studies reported that information technology had an impact on the work environment [19],[20], and information technology triggered changes in business models [21],[22]. Thus, the internet could lead to the creation of jobs and business models.

Based on the identification of various problems as described previously, this study aims to determine factors such as education, environment, and availability of internet services in influencing student interest to practice the online business.

The researchers' assumptions are based on several studies from the research background pointing out that education, environment and availability of internet services affect a person's interest in practicing the online business (Figure 1)

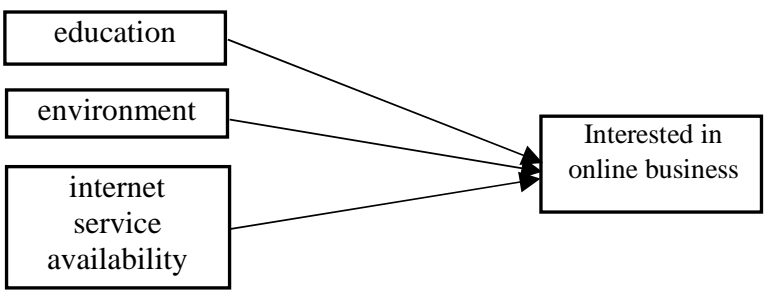

Figure 1. Research Model

\section{METHOD}

This study type is classified as associative research. This study was developed with a crosssectional model, in which the researchers solely conducted observations at one time, performed simultaneously by distributing questionnaires to research subjects in order to obtain primary data. 
Specifically for this study, the researchers intended to analyze the relationship between education, environment and availability of internet services with student interest in practicing the online business.

The population in this study included the students from the Faculty of Economics, in State University of Medan. Meanwhile, the research sample included the students of the digital business and entrepreneurship study program at the Faculty of Economics in State University of Medan, amounting to 94 respondents. The reasons for the involvement of the two study programs as the subject of research was based on the fact that the student of the digital business and entrepreneurship was a pilot project for business graduates from the Unimed, Faculty of Economics, serving as the core business at State University of Medan. Sampling techniques applied the nonprobability sampling which was incidental sampling.

Research data collection techniques was performed through questionnaire distribution. Questionnaire generally refers to a data collection technique conducted by presenting a set of written questions to respondents. For all the statements in this questionnaire, the five alternative answers are provided using a Likert scale, designed to test the respondent's degree of agreement with a statement or question.

\section{RESULTS AND DISCUSSION}

The results of this study explain two things, namely the results of partial testing and the results of simultaneous testing of independent variables on the dependent variable.

The results of the partial test of this study were conducted to determine the effect of education, environment and availability of internet services on students' interest in committing the online business. The results of partial hypothesis testing are illustrated in Table 1.

Table 1. Result of t-test (partial)

\begin{tabular}{|c|c|c|c|c|c|c|}
\hline & \multirow[t]{2}{*}{ Model } & \multicolumn{2}{|c|}{$\begin{array}{l}\text { Unstandardized } \\
\text { Coefficients }\end{array}$} & \multirow{2}{*}{$\begin{array}{c}\text { Standardized } \\
\text { Coefficients } \\
\text { Beta }\end{array}$} & \multirow{2}{*}{$t$} & \multirow{2}{*}{ Sig } \\
\hline & & $B$ & $\begin{array}{c}\text { Std. } \\
\text { Error }\end{array}$ & & & \\
\hline \multirow{4}{*}{1} & (Constant) & 1.108 & 1.979 & & .560 & .577 \\
\hline & Education & .369 & .099 & .348 & 3.275 & .000 \\
\hline & Environment & .139 & .124 & .104 & 1.125 & .263 \\
\hline & $\begin{array}{l}\text { Internet } \\
\text { availability }\end{array}$ & .341 & .072 & .432 & 4.768 & .000 \\
\hline
\end{tabular}

Table 1 indicates that the regression model of this study is as follows:

$$
\mathrm{Y}=1,108+0,369 \mathrm{X} 1+0,139 \mathrm{X} 2+0,341 \mathrm{X} 3+\mathrm{e} .
$$

The regression equation has meanings as described below. First, the tcount value of the education variable $>$ ttable value $(3.725>1.662)$ and a significant value $(0.000<0.05)$ so it can be concluded that the education variable has a positive and partially significant effect on student interest in online business. This means that if the value of the education variable increases, the value of online business interest will also increase.

Second, the t-count value of environmental variable is $<$ than t-table value $(1.125<1.662)$ with a significant value $(0.263>0.05)$. This value indicates that the environmental variable has a positive but not partially significant effect on online business interest. This positive value means that if the value of environmental variable increases, the value of online business interest will also increase.

Third, the tcount value of the internet service availability variable $>$ ttable value $(4.768>1.662)$ and a significant value $(0.000<0.05)$ so it can be concluded that the internet service availability variable has a positive and partially significant effect on online business interest. Thus, if the variable value of internet service availability increases, the value of online business interest will increase.

The next stage is to focus on $\mathrm{F}$ value, by navigating whether the independent variables consisting of education, environment and the availability of internet services included in the regression model have a joint influence on the dependent variable, namely interest in doing business online.

Table 2. Result of F-test (simultaneous)

\begin{tabular}{|c|c|c|c|c|c|c|}
\hline & Model & $\begin{array}{c}\text { Sum of } \\
\text { Squares }\end{array}$ & $d f$ & $\begin{array}{l}\text { Mean } \\
\text { Square }\end{array}$ & $F$ & Sig. \\
\hline \multirow{3}{*}{1} & Regression & 399.938 & 3 & 133.313 & 47.144 & $.000^{b}$ \\
\hline & Residual & 254.498 & 90 & 2.828 & & \\
\hline & Total & 654.436 & 93 & & & \\
\hline
\end{tabular}

The value of F-table in Table 2 is 2.71 (at level $=$ 0.05 ; degrees of freedom of numerator is $=\mathrm{k}-1=4-1$ $=3$; and degrees of freedom of denominator is $=\mathrm{n}-\mathrm{k}=$ $94-4=90$ ). Thus, based on the values in table 6 , it is apparent that the Fcount value is $47.144>$ Ftable value is 2.71 with a significance level of $0.000<$ of 0.05 .

The comparison of the two indicates that the effect of education, environment, and availability of internet services simultaneously has an influence on student interest in doing online business, which is significant.

In sum, the researchers analyze the results of the determinant coefficient test (R2) to navigate the 
variation in the value of the dependent variable, influenced by the variation in the value of the independent variable.

Table 3. Result of determination test

\begin{tabular}{crrrr} 
Model & $R$ & R.Square & $\begin{array}{c}\text { Adjusted } \\
R \text { Square }\end{array}$ & $\begin{array}{r}\text { Std. Error of } \\
\text { the estimate }\end{array}$ \\
\hline 1 & $.782^{a}$ & .611 & .598 & 1.68159 \\
\hline a. Predictors: (Constant), Internet Services, &
\end{tabular}

Environment, Education

Based on the presented Table 3, it is apparent that the value of $\mathrm{R}=0.782$, which means that the relationship among the variables of education, environment, and availability of internet services on the dependent variable of online business interest (Y) is $78.2 \%$, indicating a close relationship. The adjusted $\mathrm{R}$ Square value of 0.598 means that $59.8 \%$ of the variables of interest in conducting online business can be explained by the variables of education, environment and availability of internet services. Meanwhile, the remaining $40.2 \%$ interest in doing online business is explained by other variables, not examined in this study.

The results further indicate that simultaneously all the variables of education, environment and availability of internet services presents a positive and significant effect on student's online business interest. Partially, the education factor is positive and significant, and availability of internet service has a positive and significant effect on the interest in doing online business. Meanwhile, environmental variable indicates a positive but not significant effect.

The results further confirm that education factor has a positive and significant effect on the interest in doing online business, indicating that if the education factor increases, the student's interest in doing online business will also increase. The results of this study are in line with the results of research conducted by [23],[24],[25]). All these studies lead to the conclusion that education, training and other related activities have an influence on the interest in doing online business.

The results of environmental variable on the interest in doing online business indicate a positive but not significant effect on online business interest. The results further denote that if environmental factors increase, student interest in doing online business will also increase but the relationship is not real or meaningless. Therefore, the results of this study are different from the results of studies that have been reviewed in previous literatures [26],[27],[28].

Meanwhile, availability of internet services has an influence on the interest in doing online business. The data has proven that the internet service availability factor has a positive and significant effect, confirming that if the internet service availability factor increases, the student's interest in doing online business will also increase.

Thus, the results of this study are in accordance with research conducted by previous studies which also informed that the internet availability affects the business [21],[29],[30].

\section{CONCLUSIONS}

This study has attempted to examine how education, the environment and the availability of internet services determine student interest in doing online business among students of the digital business and entrepreneurship study program at State University of Medan.

There are several findings from this study. First, education variable and availability of internet services have a positive and significant effect on student interest in doing online business. However, specifically for environmental variable, although it has a positive effect, it depicts insignificant results on student interest in doing online business. Second, all the variables when tested simultaneously have a significant effect on students' interest in doing online business.

Therefore, although it appears that there is a significant difference between the independent variables on the dependent variable in this study, especially for environmental variables, this conclusion could not be generalized, as environment variable in several studies becomes a determinant for the emergence of one's interest in doing online business.

\section{ACKNOWLEDGMENTS}

This research was funded by the State University of Medan from the unimed PNBP basic research program in 2021 .

\section{REFERENCES}

[1] S. N. Fatoni, C. Susilawati, L. Yulianti, and Iskandar, "Dampak COVID-19 terhadap perilaku konsumen dalam penggunaan e-wallet di Indonesia," J. Chem. Inf. Model., vol. 53, no. 9, 2020, pp. 1689-1699.

[2] G. Dovgal, N. Goncharenko, and Y. Fomina, "Digital transformation of the business environment: prospect and paradoxes," Soc. Econ. Asp. INTERNET Serv. Mark. Dev., 2021, p. 55. 
[3] M. Pangestu, "Studi komparatif e-service quality ecommerce luar negeri dan ecommerce dalam negeri (Studi pada Pengguna Shopee dan Tokopedia).” 2020.

[4] J. Fadhilah, C. A. A. Layyinna, R. Khatami, and F. Fitroh, "Pemanfaatan Teknologi Digital Wallet Sebagai Solusi Alternatif Pembayaran Modern: Literature Review," J. Comput. Sci. Eng., vol. 2, no. 2, 2021, pp. 89-97.

[5] D. H. Sharma, C. A. Dhote, and M. M. Potey, "Identity and Access Management as Securityas-a-Service from Clouds," Procedia Comput. Sci., vol. 79, 2016, pp. 170-174, doi: 10.1016/j.procs.2016.03.117.

[6] A. Opinion, S. Channels, G. Comparison, and K. Market, "Digital Markets $\square$ eCommerce," in Introduction to Digital Economics, Springer, 2021, pp. 243-258.

[7] E. F. Wulandari, "Pengaruh program learning \& development dalam pengembangan kompetensi karyawan yang mengarah pada kompetensi digital terhadap pencapaian transformasi digital: Studi pada PT Telkom Akses Malang," Universitas Islam Negeri Maulana Malik Ibrahim, 2021.

[8] I. Gunawan, T. S. Fung, and D. Silaswara, "Digital Marketing Study, Through Instagram Media Case Study of Private Universities in the Tangerang Region," Primanomics J. Ekon. Bisnis, vol. 18, no. 2, 2020, p. 1, doi: $10.31253 /$ pe.v18i2.346.

[9] D. Anggrianto, E. T. Djatmika, and W. P. Rahayu, "Entrepreneurial Intention: The Moderating Role of Improvisation on Student Faculty of Economics, State University of Malang," J. Bus. Manag. Rev., vol. 2, no. 4, 2021, pp. 318-335, doi: $10.47153 / \mathrm{jbmr} 24.1342021$.

[10] D. Iskamto and Jenita, "Analysis of Atittude factors Toward Entrepreneurial Intention in Indonesian," KnE Soc. Sci., 2020, pp. 483-491, doi: $10.18502 / \mathrm{kss} . v 4 \mathrm{i} 9.7346$.

[11] R. B. Amanamah, E. K. Owusu, and A. Acheampong, "Barriers to Entrepreneurial Intention Among Univeristy Students In Ghana," Eur. J. Res. Reflect. Educ. Sci., vol. 6, no. 1, 2018, pp. 29-43.

[12] L. von Arnim and M. Mrozewski, "Entrepreneurship in an increasingly digital and global world. Evaluating the role of digital capabilities on international entrepreneurial intention," Sustain., vol. 12, no. 19, 2020, pp. 1-
18, doi: 10.3390/su12197984.

[13] H. Hassan, A. B. Sade, and M. S. Rahman, "Shaping entrepreneurial intention among youngsters in Malaysia," J. Humanit. Appl. Soc. Sci., vol. 2, no. 3, 2020, pp. 235-251, doi: 10.1108/jhass-02-2020-0029.

[14] L. Li and D. Wu, "Entrepreneurial education and students' entrepreneurial intention: does team cooperation matter?," J. Glob. Entrep. Res., vol. 9, no. 1, 2019, pp. 1-13, doi: 10.1186/s40497019-0157-3.

[15] Y. . Kim, "The Effects of Entrepreneurship Education, Entrepreneurial Competence and Attitude on Undergraduate Entrepreneurial Intention," Asia-Pacific J. Bus. Ventur. Entrep., vol. 12, no. 2, 2017, pp. 13-20, doi: 10.16972/apjbve.12.2.201704.13.

[16] R. K. Jena, "Measuring the impact of business management Student's attitude towards entrepreneurship education on entrepreneurial intention: A case study," Comput. Human Behav., vol. 107, 2020, p. 106275, doi: 10.1016/j.chb.2020.106275.

[17] A. I. Aleidi and D. Chandran, "Does institutional environment promote women's it entrepreneurial intentions in Saudi Arabia? Technological and institutional perspectives," in Proceedings of the 21st Pacific Asia Conference on Information Systems: "'Societal Transformation Through IS/IT'”, PACIS 2017, 2017.

[18] G. H. S. M. de Moraes, E. S. Iizuka, and M. Pedro, "Effects of Entrepreneurial Characteristics and University Environment on Entrepreneurial Intention," Rev. Adm. Contemp., vol. 22, no. 2, 2018, pp. 226-248, doi: 10.1590/1982-7849rac2018170133.

[19] P. de Camargo Fiorini and C. J. C. Jabbour, "Information systems and sustainable supply chain management towards a more sustainable society: Where we are and where we are going," Int. J. Inf. Manage., vol. 37, no. 4, 2017, pp. 241249, doi: 10.1016/j.ijinfomgt.2016.12.004.

[20] A. Ali, D. Warren, and L. Mathiassen, "Cloudbased business services innovation: A risk management model," Int. J. Inf. Manage., vol. 37, no. 6, 2017, pp. 639-649, doi: 10.1016/j.ijinfomgt.2017.05.008.

[21] L. Markfort, P. Koegler, A. Arzt, and H. Gebauer, "BUSINESS MODEL PATTERNS OF IOT PLATFORMS IN THE B2B CONTEXT," Adv. Serv. Sustain. Growth, 2020, p. 561.

[22] R. Schmuck, "The Use of Online Business 
Models," Procedia Manuf., vol. 54, 2021, pp. 45-51.

[23] L. S. L. Lai and W. M. To, "E-Entrepreneurial intention among young Chinese adults," Asian J. Technol. Innov., vol. 28, no. 1, 2020, pp. 119137, doi: 10.1080/19761597.2020.1713832.

[24] M. Mugiono, S. D. W. Prajanti, and W. Wahyono, "The Effect of Digital Literacy and Entrepreneurship Education Towards Online Entrepreneurship Intention Through Online Business Learning and Creativity At Marketing Department in Batang Regency," J. Econ. Educ., vol. 10 , no. 1,2020 , pp. 21-27.

[25] C. G. Iwu et al., "Entrepreneurship education, curriculum and lecturer-competency as antecedents of student entrepreneurial intention," Int. J. Manag. Educ., vol. 19, no. 1, 2021, p. 100295, doi: 10.1016/j.ijme.2019.03.007.

[26] R. H. Trivedi, "Entrepreneurial-intention constraint model: A comparative analysis among post-graduate management students in India, Singapore and Malaysia," Int. Entrep. Manag. J., vol. 13, no. 4, 2017, pp. 1239-1261, doi: 10.1007/s11365-017-0449-4.

[27] M. R. M. Barral, F. G. Ribeiro, and M. D. Canever, "Influence of the university environment in the entrepreneurial intention in public and private universities," RAUSP Manag. J., vol. 53, no. 1, 2018, pp. 122-133, doi: 10.1016/j.rauspm.2017.12.009.

[28] I. Martins and J. P. Perez, "Testing mediating effects of individual entrepreneurial orientation on the relation between close environmental factors and entrepreneurial intention," Int. J. Entrep. Behav. Res., vol. 26, no. 4, 2020, pp. 771-791, doi: 10.1108/IJEBR-08-2019-0505.

[29] M. T. Sultan and F. Sharmin, "An exploratory investigation of facebook live marketing by women entrepreneurs in bangladesh," in Lecture Notes in Computer Science (including subseries Lecture Notes in Artificial Intelligence and Lecture Notes in Bioinformatics), vol. 12195 LNCS, 2020, pp. 415-430, doi: 10.1007/978-3030-49576-3_30.

[30] J. Ma and H. Xu, “College students' network entrepreneurship model based on FPGA and machine learning," Microprocess. Microsyst., 2020, p. 103504, doi:

10.1016/j.micpro.2020.103504. 